\title{
Anabaena fuscovaginata (Nostocales), a new cyanobacterial species from periphyton of the freshwater alkaline marsh of Everglades, South Florida, USA.
}

\author{
Jan MAREš \\ University of South Bohemia, Faculty of Science, Branišovská 31, CZ-37005 České Budějovice, Czech Republic, \\ e-mail:maresj01@prf.jcu.cz
}

\begin{abstract}
A new species of the nostocalean genus Anabaena was discovered in periphytic cyanobacterial mats of the Everglades marsh, South Florida, USA. In some of the 10 samples where it occurred, the species dominated the cyanobacterial community, however, it was always part of a rich assemblage of microbiota, including many types characteristic for alkaline herbaceous wetlands of Caribbean America or freshwater tropical marshes. On the basis of typical morphological traits and occurrence in a periphytic habitat, I suggest that the species is a member of the genus Anabaena in its original sense, valid after recent separation of planktic taxa. As the most distinctive morphological feature, it has firm, coloured sheaths that have never been reported for this genus before.
\end{abstract}

Key words: alkaline marshes, Anabaena, cyanobacteria, Everglades, morphology, periphyton, taxonomy

\section{Introduction}

The concept of a species in Cyanobacteria and characters necessary for taxonomic description of new taxa have been a subject of continual debate among concerned researchers. The modern polyphasic approach, introduced for cyanobacteria by ANAGNostidis \& KomÁreK $(1985,1988,1990)$, KomÁREK \& ANAGNOSTIDIS $(1986,1989)$ and since then further developed and applied by scientists all over the world (recently e.g. CASAMATTA et al. 2006; Fiore et al. 2007; Finsinger et al. 2008; McGregor \& Rasmussen 2008; Palinska \& MARQUARDT 2008, and many others), has proved to be the best available tool for reliable and objective taxonomical conclusions. This approach requires the synthesis of detailed description of classical morphological traits, ecology, life history, cell ultrastructure and molecular phylogeny into a congruent picture of a species defined by both unique genetic and phenotypic markers.

Unfortunately, in some cases it is notpossible to fulfil all these expectations and provide complete characterization of a species within a single study. For various reasons, some cyanobacterial taxa do not grow well in cultures or cannot be returned to the laboratory alive for cultivation and molecular studies. In our experience, this especially applies to material from either countries with few laboratory facilities, inaccessible sites, or highly specific habitats. A phycologist has to answer the question: Is it worth describing the morphological diversity of the material even if I cannot characterize its genetic identity? In my opinion, it is always useful to record the biodiversity as well as possible, thus providing at least basic data for improvements by further researchers. This approach is important in taxonomically little explored and ecologically distinct habitats where there is a great number of unknown (but characteristic) types of cyanobacteria. Examples of such environments are wetlands and forests of the tropics, high mountains, and other centers of biodiversity. In these situations, I suggest that new cyanobacterial taxa should be described according to the International Code of Botanical Nomenclature (MCNeILL et al. 2006), based exclusively on morphological and ecological characteristics. It should be emphasised that the descriptions should be as precise and detailed as possible, and always accompanied by good-quality images of the material for further comparisons.

One habitat that fits these considerations is the alkaline (sub)tropical shallow marsh. Such wetlands are largely found in warm parts of America, especially the Caribbean 
region: Yucatán Peninsula and South Florida (Everglades), Cuba, Venezuela, Puerto Rico, and at minor sites elsewhere. This type of marsh is characterised by raised $\mathrm{pH}$ (e.g. in Belize $\mathrm{pH}=7.5-8.8$, after REJMÁNKOVÁ et al. 2004), usually a nutrient-poor environment, fluctuating water levels, and characteristic communities of aquatic plants with extensive accumulations of calcified cyanobacteria-dominated periphytic mats. Thorough observations of the ecology, hydrology, geology and biota and possible means of protection of this peculiar type of wetland can be found in Davis \& OGden (1994), RejMÁnKová et al. (1996), ReJMÁNKová \& KomÁrKová (2000) and RICHARDSON (2008).

The species composition of cyanobacteria at several sites has been studied using modern taxonomic approaches. For instance, more than 80 species were found in the wetlands of Cuba (14 new taxa to science, cf. KoMÁreK 1984a,b, 1989a,b, 1995, 2005) and 65 species in the alkaline marshes of northern Belize (19 new to science, cf. KomÁreK \& KomÁrková-Legnerová 2007; TURICCHIA et al. 2009). On the other hand, the systematics of the periphytic cyanobacteria of Florida Everglades have been little studied, and usually only a few dominant species have been noted (Gleason 1974; VyMAZAL \& Richardson 1995; McCormick \& O'Dell 1996). Application of a more comprehensive examination (MAREŠ 2006) revealed great diversity of morphotypes, some of which evidently represented unknown species. So far only one of them has been described as a new species (Wolskyella floridana Mareš et Kaštovský, cf. MAReš et al. 2008).

In this study, I present a new species of Anabaena (Nostocales, Cyanobacteria) from the periphyton of Everglades that in my opinion also deserves valid taxonomic description due to its conspicuous phenotype and unique locality of occurrence.

\section{Materials and Methods}

The samples of cyanobacterial mats were collected in November 1999 inside the borders of the Water Conservation Area 2A of Everglades, South Florida, USA, at the sampling points $\mathrm{C} 3, \mathrm{C} 4$ and $\mathrm{C} 5$ (for maps and detailed description of the area see VyMAZAL et al. 2002). These were the rather less impacted or unimpacted sites of a nutrient enrichment gradient caused by long-term agricultural runoff (water column total phosphorus concentration less or equal to $\left.14 \mu \mathrm{g} . \mathrm{L}^{-1}\right)$. The locality was mostly ecologically similar to the original oligotrophic alkaline wetland, dominated by a community of emergent and submersed macrophytes with abundant periphyton encrusted by calcium carbonate.

The material was preserved in $1.5 \%$ formaldehyde and observed by optical microscopy with differential interference contrast. Morphology of the species was documented by means of digital photography and drawings based on examination of 10 different samples (mats).

\section{Results}

The described species of Anabaena dominated the periphytic assemblage at least in some of the samples. In material from site $\mathrm{C} 3$ it sometimes contributed up to $50 \%$ of total biomass according to my estimations. It retained its characteristic features also in samples where it was scarce. The observed set of populations provided sufficient morphological and ecological data to separate it from existing taxa as a new species under the International Code of Botanical Nomenclature.

\section{Anabaena fuscovaginata MAREš, sp. nov.}

Diagnosis: Stratum micro- ad macroscopicum, prostratum, submersum. Fila in fasciculis dense agglomerata et intricata vel inter cyanobacteria periphytica dispersa; mucilago sine colore, diffusus, interdum promptus. Trichoma sinuata, uniseriata, non ramosa, ad dissepimenta constricta, 2.5-5 $\mu \mathrm{m}$ lata, paucim ad extremitatis attenuata, metamerica, cum (2-) 6-18 (-25) cellulis vegetatibus inter heterocytas. Akinetes heterocytarum utrinque contiguae, solitariae vel raro 2 (-3)-seriatae. Vaginae adsunt vel gelatinosae, laeves, hyalinae vel luteo-fuscae, ad $2 \mu \mathrm{m}$ latae, praecipue ad heterocytis akinetisque evolutae. Cellulae cylindricae ad doliiformae, isodiametricae vel paucim longior quam latae, $2.5-3.5(-5) \times 2.5-7(-8) \quad \mu m$, aeruginosae, contentu praecipue granuloso; cellula apicalis paucim elongata, plus minusve obtuse conica. Heterocytae intercalares, solitariae, sphaerice cylindricae, praecipue duplo longiores quam latae, 3.5-5 (-7) × (5.5-) 7.5-10 (-12) um. Akinetes cylindricae ad cylindricae-ovatae, apicibus rotundatis, 7-10 (-13) × (10-) 14-20 (-25) $\mu \mathrm{m}$, heterocytas contiguis, episporio laevi, pallide et translucente lutescenti in akinetis maturis.

Habitatio: Periphytice metaphyticeque inter algas cyanobacteriasque, interdum in massis, in 
paludibus alkalinis, oligotrophicis, subtropicis cum vegetatio submerso. - Locus classicus: America septentrionalis, Florida-Everglades, in area dicto Water Conservation Area $2 A$.

Collectio conservata deposita in: BRNM HY 1.431 depositus (coll. Jan Kaštovský, 23.09.1999); iconotypus : figura nostra 1.

Filaments densely agglomerated and entangled in clusters or dispersed among other cyanobacteria in periphyton; trichomes are sometimes enveloped by a fine and diffluent colourless mucilage. Trichomes wavy, constricted at cross walls, somewhat attenuated towards ends, 2.5-5 $\mu \mathrm{m}$ wide, with a regular metameric structure - one heterocyte usually occurs per (2-) 6-18 $(-25)$ vegetative cells, akinetes always on both sides of the heterocyte, single or rarely $2(-3)$ in a row. Sheath smooth, gelatinous, brownishyellow, sometimes colourless, up to $2 \mu \mathrm{m}$ wide, usually covering the heterocyte, the neighbouring akinetes and a few adjacent cells, rarely absent. Vegetative cells barrel-shaped, longer than wide or isodiametric, $2.5-3.5(-5) \times 2.5-7(-8) \mu \mathrm{m}$, with blue-green, granulated contents. Apical cells are a little longer, conical or rounded-conical in well-developed trichomes. Heterocytes rounded cylindrical, 3.5-5 (-7) × (5.5-) 7.5-10 (-12) $\mu \mathrm{m}$, (1.2-) 1.7-2 $\times$ longer than wide. Akinetes rounded cylindrical, 7-10 (-13) × (10-) 14-20 (-25) $\mu \mathrm{m}, 1.5-2.5 \times$ longer than wide, with smooth translucent yellowish walls.

Freshwater, scattered among other cyanobacteria and algae, sometimes dominant, in periphyton. Recorded from the Florida Everglades, USA, a subtropic alkaline oligotrophic marsh with herbaceous vegetation (Figs. 1, 2).

\section{Discussion}

This new cyanobacterial species, Anabaena fuscovaginata, shows many typical characters attributed to the genus in its original sense: benthic types, growing in macroscopic mats, without aerotopes (Bornet \& Flahault 1888; KomáreK \& HAUER 2010). By the regularly metameric structure of filaments (Fig. 2s), with few paraheterocytic akinetes, it can be easily distinguished from similar genera with benthic species like Nostoc, Trichormus, Cylindrospermum, etc. (КомÁReK \& AnAgnostidis 1989; RAJANIEMI et al. 2005). Importantly, typical benthic Anabaena (former subg. Anabaena) have been shown to have significant genetic differences from planktic types (former subg. Dolichospermum) that are phylogenetically closer to Aphanizomenon (Gugger et al. 2002; RAJANiemi et al. 2005; KomÁreK \& KomÁrKovÁ 2006). The taxonomy of planktic cyanobacteria formerly included in the genus Anabaena has been further studied, and recently, new genera Dolichospermum (КоMÁREK \& ZAPOMĚLOVÁ 2007, 2008; WACKLIN et al. 2009) and Sphaerospermopsis (ZAPOMĚLOVÁ et al. 2009, 2010) have been separated from Anabaena on the basis of polyphasic data. Given the morphological and ecological variability inside the former widely defined genus Anabaena, further revisions should be expected, perhaps also including the benthic types.

Anabaena fuscovaginata is apparently a member of a group of similar taxa characterized by periphytic or metaphytic origin and morphology of filaments (Table 1). These are somewhat attenuated towards ends (Fig. $2 \mathrm{k}-\mathrm{q}$ ), having akinetes on both sides of the heterocytes (Fig. $2 \mathrm{a}-\mathrm{j}$ ). They have been discussed previously, for example by KомÁReк (2005) in his study of several periphytic species from Cuba. Morphologically, A. fuscovaginata can be distinguished from them by the generally smaller width of trichomes, and by the presence of coloured sheaths (Tables 2, 3, Fig. 2). Interestingly, in my samples two similar taxa occurred, $A$. ambigua $\mathrm{C}$. B. RAo and $A$. iyengarii BHARADWAJA, often accompanying $A$. fuscovaginata. Both were originally described from India, but they probably represent pantropical species that can be found in periphyton of rather unenriched shallow freshwaters and marshes of warm areas all over the world (also reproted from the Caribbean area, Cuba by KoMÁREK 2005). A similar pattern of distribution might be expected in our new species. In support of this contention, the cyanobacterial community in my samples consisted of a considerable number of other morphotypes, many of which could be assigned to known pantropical species (MAREŠ 2006). Alternatively, considering that it has never been reported before from any other tropical or subtropical marshland, it might be restricted to alkaline wetlands of a certain type. Such distribution was already reported for example for Gomphosphaeria semen-vitis (КОMÁREK 1989a; KomÁreK \& KomÁrkovÁ-Legnerová 2007).

Remarkably, I observed a rather firm, gelatinous and intensely coloured sheath, 
Table 1. List of morphospecies similar to A. fuscovaginata and their distribution.

\begin{tabular}{|c|c|c|c|}
\hline Species & Reference & Distribution & Habitat \\
\hline A. ambigua RAO 1937 & DESIKACHARY 1959, KOMÁREK 2005 & pantropical & $\begin{array}{l}\text { periphyton, } \\
\text { facultatively } \\
\text { plankton }\end{array}$ \\
\hline A. bornetiana Collins 1896 & GeItler 1932, KOMÁREK 2005 & $\begin{array}{l}\text { North and Central } \\
\text { America }\end{array}$ & $\begin{array}{l}\text { metaphyton, } \\
\text { floating clusters }\end{array}$ \\
\hline A. fuscovaginata sp. nov. & described here & Everglades, Florida & periphyton \\
\hline A. iyengarii BHARADWAJA 1935 & DESIKACHARY 1959, KOMÁREK 2005 & pantropical & metaphyton \\
\hline A. oblonga De WiLdEMAn 1897 & KOMÁREK 1989b, 2005 & pantropical & periphyton \\
\hline A. orientalis DIXIT 1936 & DESIKACHARY 1959, KOMÁREK 2005 & pantropical & metaphyton \\
\hline $\begin{array}{l}\text { A. turkestanica (A. KISELEV) } \\
\text { KoMÁREK } 2005\end{array}$ & $\begin{array}{l}\text { KoMÁREK 2005, ElENKIN 1938, } \\
\text { HollERBACH et al. } 1953\end{array}$ & Central Asia, Cuba & metaphyton \\
\hline
\end{tabular}

Table 2. Comparison of morphospecies similar to A. fuscovaginata [ + present; $(+)$ rarely present; ? not known; B brown].

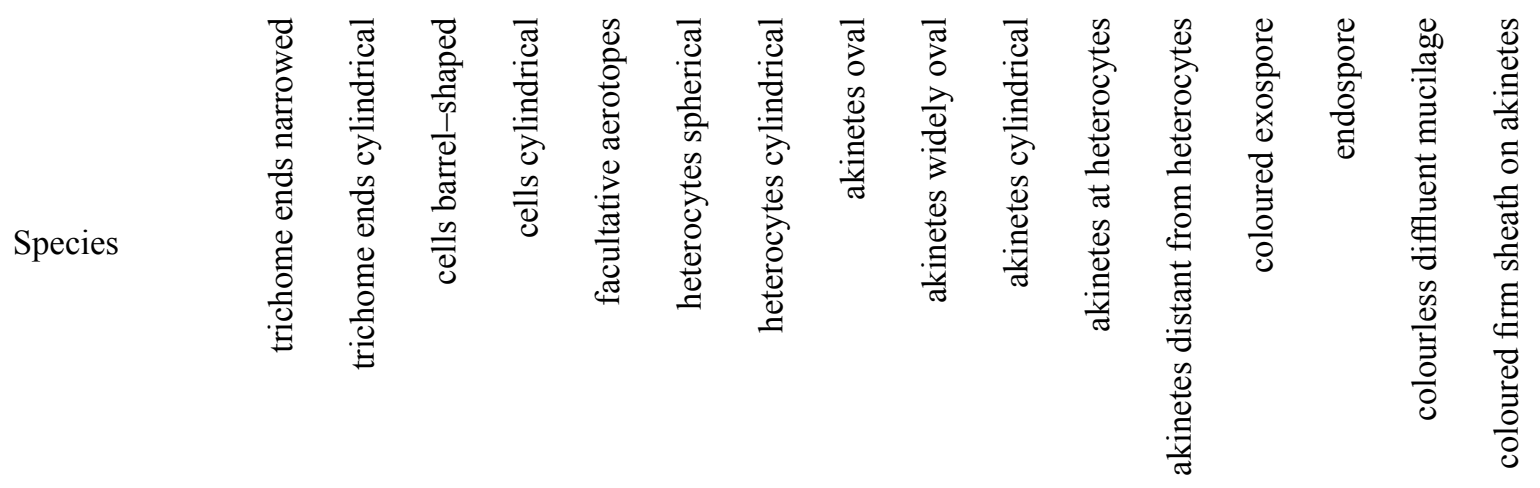

\begin{tabular}{|c|c|c|c|c|c|c|c|c|c|c|c|c|c|c|c|c|}
\hline A. ambigua & $(+)$ & & + & & + & + & & & + & & + & & & & $?$ & \\
\hline A. bornetiana & & + & + & & & + & & & & + & & + & & & - & \\
\hline A. fuscovaginata & + & & + & + & & & + & & & + & + & & + & & + & + \\
\hline A. iyengarii & & + & + & & & + & + & + & + & + & + & & & & + & \\
\hline A. oblonga & + & & + & & & & + & & & + & & + & $(+)$ & & $?$ & \\
\hline A. orientalis & + & & & + & & & + & + & & & + & & $(+)$ & $\mathrm{B}$ & $?$ & \\
\hline A. turkestanica & + & & + & & & + & $(+)$ & & + & & + & & & & + & \\
\hline
\end{tabular}




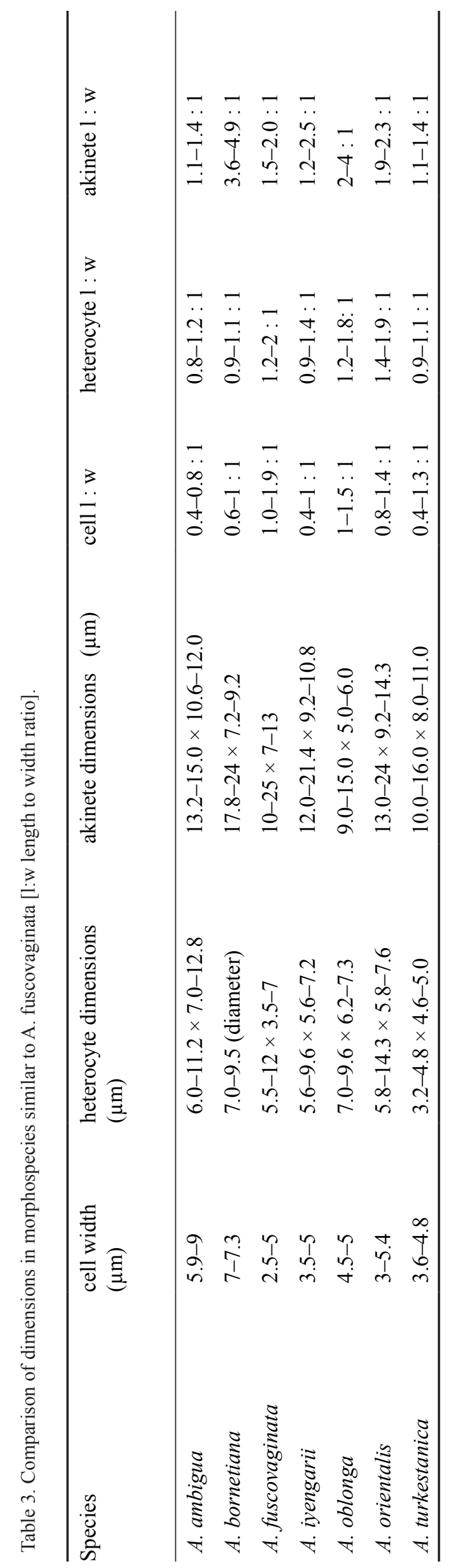

covering most of the A. fuscovaginata filaments (Fig. 2). No report of this phenomenon has been found for Anabaena, yet. According to the generic description, mucilaginous envelopes are quite common in the genus, but usually in a colourless and rather diffluent form (also occasionally visible in A. fuscovaginata, Fig. $2 \mathrm{u}-\mathrm{v}$ ) while firm and coloured sheaths are typical for other nostocalean genera (for example Scytonema). Whether or not this characteristic phenotypic trait should have taxonomic implications at the generic level, has to be finally resolved by polyphasic approach, including molecular-phylogenetic study. Until then, considering the overall similarity in all other recorded characteristics, I suggest keeping the species within Anabaena.

\section{Acknowledgements}

The author thanks Prof. C. J. Richardson from Duke University Wetland Center, North Carolina, USA and Dr. J. Kaštovský for providing the opportunity to study the material from the Everglades wetland and Prof. J. Komárek for nomenclatural advice. The paper is published with the support of the grants GA CR No. 206/08/0318 and MSM 6007665801.

\section{References}

Anagnostidis, K. \& KomÁreK, J. (1985): Modern approach to the classification system of Cyanophytes 1 - Introduction. - Archiv für Hydrobiologie/Algological Studies 38-39: 291-302.

Anagnostidis, K. \& KomÁreK, J. (1988): Modern approach to the classification system of Cyanophytes 3 - Oscillatoriales. - Archiv für Hydrobiologie/Algological Studies 50-53: 327-472.

Anagnostidis, K. \& KomáreK, J. (1990): Modern approach to the classification system of Cyanophytes 5 - Stigonematales. - Archiv für Hydrobiologie/Algological Studies 59: 1-73.

Bornet, É. \& Flahault, C. (1888): Revision des Nostocacées hétérocystées contenues dans les principaux herbiers de France. - Annales des Sciences Naturelles, Botanique 7: 177-262.

Casamatta, D. A., Gomez, S. R. \& Johansen, J. R. (2006): Rexia erecta gen. et sp. nov. and Capsosira lowei sp. nov., two newly described cyanobacterial taxa from the Great Smoky Mountains National Park (USA). - Hydrobiologia 561: 13-26.

Davis, S. M. \& Ogden, J. C. (eds) (1994): Everglades: the ecosystem and its restoration. -860 pp., St. Lucie Press, Delray Beach (FL). 


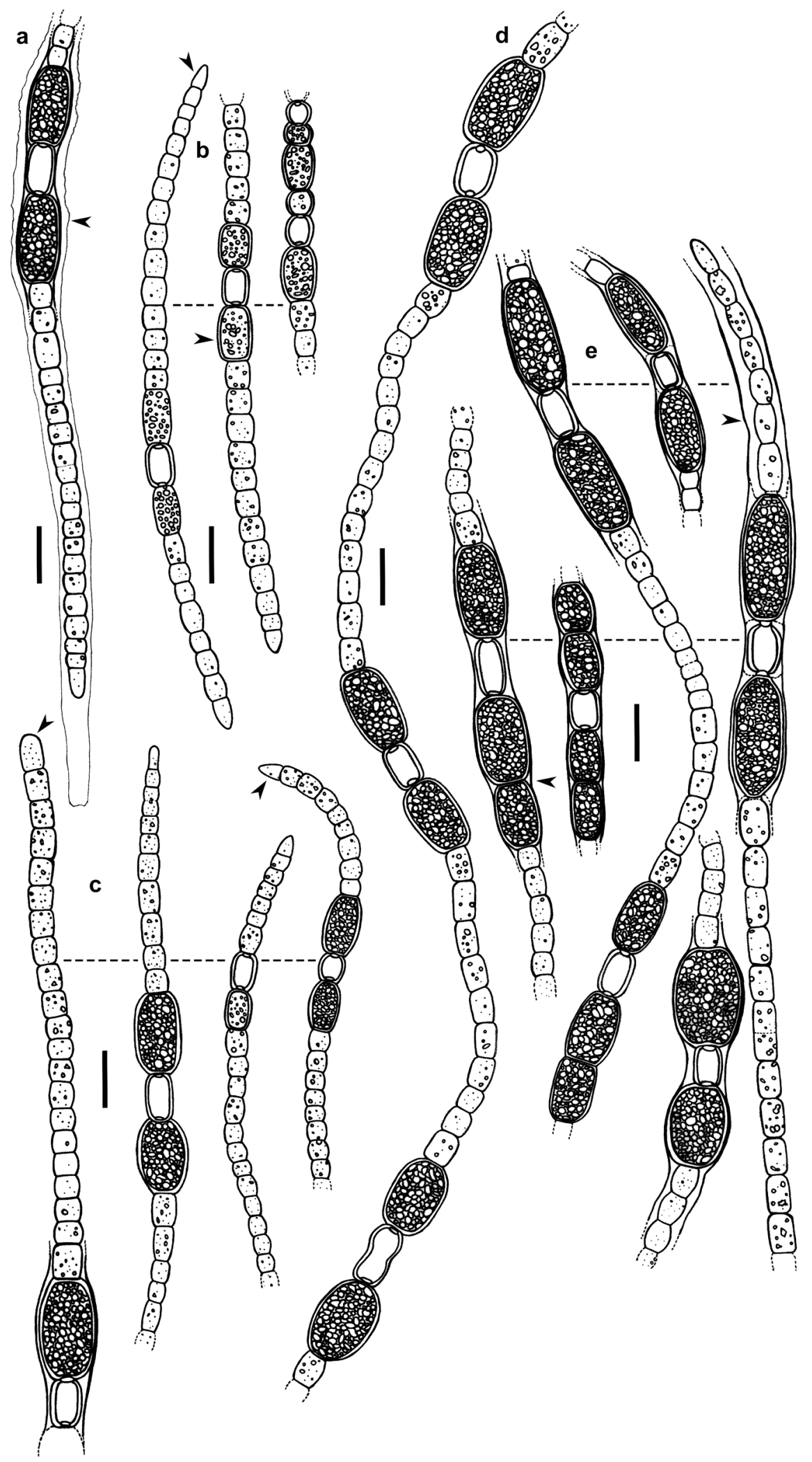

Fig. 1. Anabaena fuscovaginata: (a) filament covered by a diffluent mucilaginous envelope; (b) young filaments with emerging akinetes and narrowed ends; (c) variability of trichome ends (cylindrical to conical apical cells); (d) filament of typical metameric structure; (e) variability of ripe akinetes with gelatinous sheaths. Scale bars $10 \mu \mathrm{m}$. 


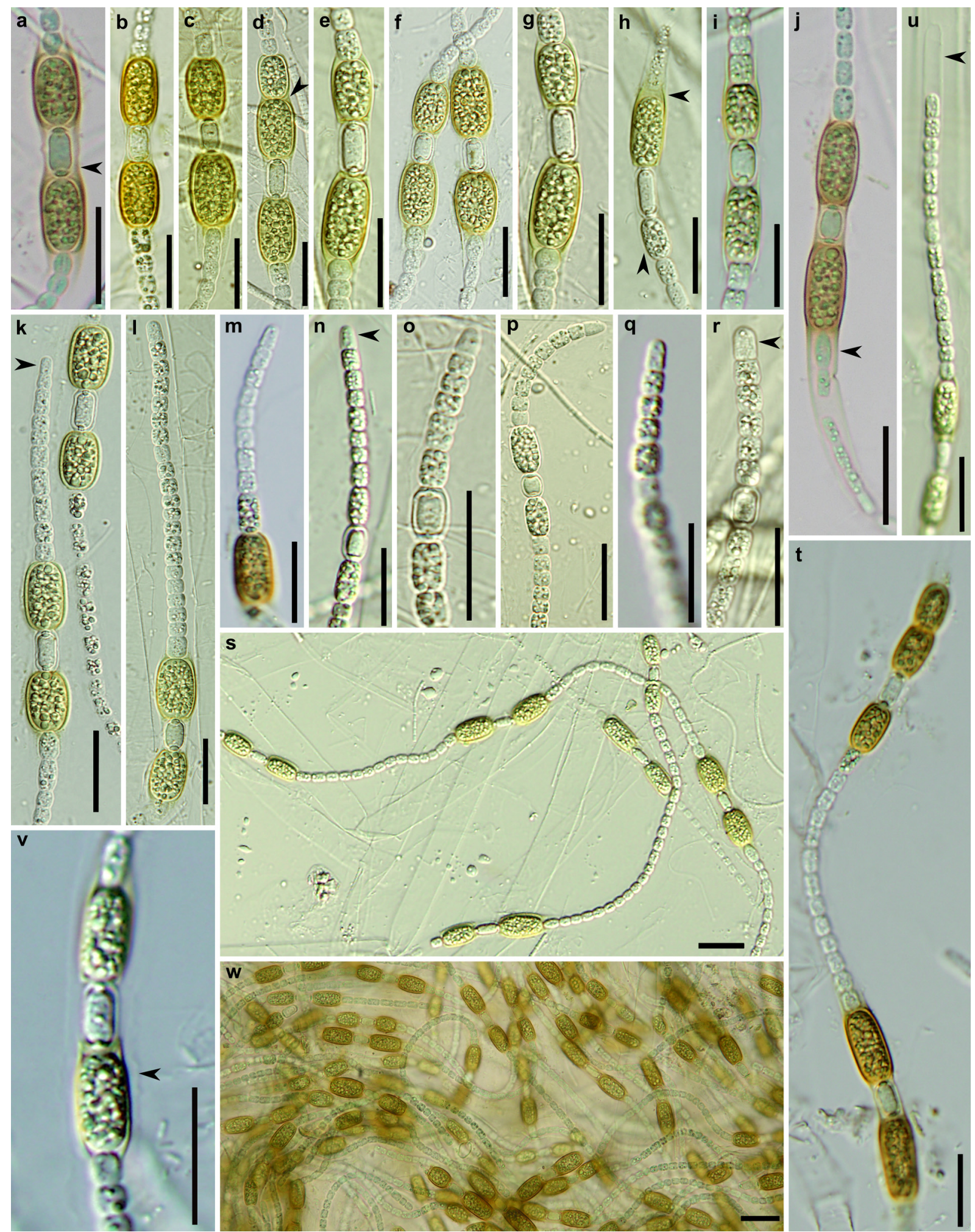

Fig. 2. Microphotographs of Anabaena fuscovaginata: $(\mathrm{a}-\mathrm{j})$ variability of akinetes and coloured gelatinous sheaths (horizontal arrows: sheaths, skewed arrow: two akinetes in a row); $(\mathrm{k}-\mathrm{r})$ variability of trichome ends (arrows - conical to cylindrical apical cells); ( $\mathrm{s}-\mathrm{t}$ ) metameric structure of the filaments; ( $\mathrm{u}-\mathrm{v}$ ) diffluent mucilaginous envelopes (arrow); (w) filaments densely clustered in a periphytic mat. Scale bars $20 \mu \mathrm{m}$. 
Desikachary, T. V. (1959): Cyanophyta. - 686 pp., I. A. C. R. monographs on algae, New Delhi.

Elenkin, A.A. (1938): Monographia algarum cyanophycearum aquidulcium et terrestrium in finibus URSS inventarum (Sinezelenye vodorosli SSSR), Pars spec. (1-2). - 1908 pp., Izdatel'stvo Akademii Nauk SSSR, MoskvaLeningrad.

Finsinger, K., Scholz, I., Serrano, A., Morales, S., Uribe-Lorio, L., Mora, M., Sittenfeld, A., Weckesser, J. \& Hess, W. R. (2008): Characterization of true-branching cyanobacteria from geothermal sites and hot springs of Costa Rica. - Environmental Microbiology 10: 460-473.

Fiore, M. F., Sant' Anna, C. L. \& Azevedo, M. T. D. (2007): The cyanobacterial genus Brasilonema, gen.nov., a molecular and phenotypic evaluation. - Journal of Phycology 43: 789-798.

Geitler, L. (1932): Cyanophyceae. - In: Rabenhorst's Kryptogamen-Flora 14 - 1196 pp., Leipzig.

Gleason, P. J. (ed) (1974): Environments of South Florida: Present and past. - 181 pp., Miami Geological Society, Miami (FL).

Gugger, M., Lyra, C., Henriksen, P., Coute, A., Humbert, J. F. \& Sivonen, K. (2002): Phylogenetic comparison of the cyanobacterial genera Anabaena and Aphanizomenon. International Journal of Systematic and Evolutionary Microbiology 52: 1867-1880.

Hollerbach M. M., Kosinskaja E. K. \& Poljanskij V. I. (1953): Sinezelenye vodorosli [Bluegreen algae]. - In: Opredelitel prosnovodnych vodoroslej SSSR 2 - 652 pp., Izdatel'stvo Sovetskaja Nauka, Moskva.

KomÁrek, J. (1984a): Sobre las cyanofíceas de Cuba: (1) Aphanizomenon volzii , (2) especies de Fortiea. - Acta Botanica Cubana 18: 30 pp.

Komárek, J. (1984b): Sobre las cyanofíceas de Cuba: (3) Especies planctónicas que forman florecimientos de las aguas. - Acta Botanica Cubana 19: 33 pp.

KomÁrek, J. (1989a): Studies on the Cyanophytes of Cuba 4-6. - Folia Geobotanica et Phytotaxonomica 24: 57-97.

KomÁrek, J. (1989b): Studies on the Cyanophytes of Cuba 7-9. - Folia Geobotanica et Phytotaxonomica 24: 171-206.

KomÁrek, J. (1995): Studies on the Cyanophytes (Cyanoprokaryotes) of Cuba 10. New and little known Chroococcalean species. - Folia Geobotanica et Phytotaxonomica 30: 81-90.

KomÁrek, J. (2005): Studies on the cyanophytes (Cyanobacteria, Cyanoprokaryota) of Cuba 11. Freshwater Anabaena species. - Preslia 77: 211-234.

KomÁreK, J. \& AnAgnostidis, K. (1986): Modern approach to the classification system of cyanophytes 2 - Chroococcales. - Archiv für Hydrobiologie/Algological Studies 43: 157226.

KomÁrek, J. \& Anagnostidis, K. (1989): Modern approach to the classification system of cyanophytes 4 - Nostocales. - Archiv für Hydrobiologie/Algological Studies 56: 247345.

Komárek, J. \& Hauer, T. (2010): CyanoDB.cz On-line database of cyanobacterial genera. - World-wide electronic publication, Univ. of South Bohemia \& Inst. of Botany AS CR, http:// www.cyanodb.cz

KomÁreK, J. \& KomÁrkovÁ, J. (2006): Diversity of Aphanizomenon-like cyanobacteria. - Czech Phycology 6: 1-32.

KomÁreK, J. \& KomÁrkovÁ-Legnerová, J. (2007): Taxonomic evaluation of cyanobacterial microflora from alkaline marshes of northern Belize. 1. Phenotypic diversity of coccoid morphotypes. - Nova Hedwigia 84: 65-111.

KomÁreK, J. \& ZAPOMĚLovÁ, E. (2007): Planktic morphospecies of the cyanobacterial genus Anabanena $=$ subg. Dolichospermum -1 . part: coiled types. - Fottea 7: 1-31.

KomáreK, J. \& ZapomĚlová, E. (2008): Planktic morphospecies of the cyanobacterial genus Anabanena $=$ subg. Dolichospermum -1 . part: straight types. - Fottea 8: 1-14.

Mareš, J. (2006): Periphytic Cyanobacteria of Everglades (Florida) and their relation to water chemistry and different substrata. - Bachelor Thesis, University of South Bohemia, Faculty of Biological Sciences, České Budějovice (http:// www.sinicearasy.cz/files/MaresJ_bc.pdf).

Mareš, J., Kaštovský, J., McGregor, G. \& KomÁreK, J. (2008): The little known pseudofilamentous cyanobacterium Wolskyella (Synechococcales). - Nova Hedwigia 87: 221-230.

McCormick, P. V. \& O’Dell, M. (1996): Quantifying periphyton responses to phosphorus in the Florida Everglades: a synoptic-experimental approach. - Journal of the North American Benthological Society 15: 450-468.

McGregor G. B. \& Rasmussen, J. P. (2008): Cyanobacterial composition of microbial mats from an Australian thermal spring: a polyphasic evaluation. - FEMS Microbiology Ecology 63: 25-35.

McNeill, J., Barrie, F. R., Burdet, H. M., Demoulin, V., Hawksworth, D. L., Marhold, K., Nicolson, D. H., Prado, J., Silva, P. C., Skog, J. E., Wiersema, J. H. \& Turland, N. J. (eds) (2006): International Code of Botanical Nomenclature (Vienna Code). Adopted by the Seventeenth International Botanical Congress Vienna, Austria, July 2005. - Regnum Vegetabile 146: 1-568. A.R.G. Gantner Verlag, Ruggell, 
Liechtenstein.

Palinska, K. A. \& Marquardt, J. (2008): Genotypic and phenotypic analysis of strains assigned to the widespread cyanobacterial morphospecies Phormidium autumnale (Oscillatoriales). Archives of Microbiology 189: 325-335.

Rajaniemi, P., Hrouzek, P., Kastovska, K., Williame, R., Rantala, A., Hoffmann, L., Komarek, J., \& Sivonen, K. (2005): Phylogenetic and morphological evaluation of the genera Anabaena, Aphanizomenon, Trichormus and Nostoc (Nostocales, Cyanobacteria). - International Journal of Systematic and Evolutionary Microbiology 55: 11-26.

Rejmánková, E., KomÁrek, J. \& KomÁrkovÁ, J. (2004): Cyanobacteria - a neglected component of biodiversity: patterns of species diversity of inland marshes of northern Belize (CentralAmerica). - Diversity \& Distributions 10: 135-153.

Rejmánková, E. \& Komárková, J. (2000): A function of cyanobacterial mats in phosphorus-limited tropical wetlands. - Hydrobiologia 431: 135153.

Rejmánková, E., Pope, K. O., Post, R. \& Maltby, E. (1996): Herbaceous wetlands of the Yucatan peninsula: Communities at extreme ends of enviromental gradients. - Internationale Revue der gesamten Hydrobiologie 81: 223-225.

Richardson, C. J. (2008): The Everglades experiments: Lessons for ecosystem restoration. - 702 pp., Springer-Verlag, New York.

Turicchia, S., Ventura, S., Komárková, J. \& KomÁrek, J. (2009): Taxonomic evaluation of cyanobacterial microflora from alkaline marshes of northern Belize. 2. Diversity of oscillatorialean genera. - Nova Hedwigia 89: 165-200.
Vymazal，J., Komárková, J., KubeČKová, K. \& KAŠTovský, J. (2002): Periphyton composition change along the phosphorus gradient in the Florida Everglades. - Czech Phycology 2: 8392.

Vymazal, J. \& Richardson, C. J. (1995): Species composition, biomass, and nutrient content of periphyton in the Florida Everglades. - Journal of Phycology 31: 343-354.

Wacklin, P., Hoffmann, L. \& Komárek, J. (2009). Nomenclatural validation of the genetically revised cyanobacterial genus Dolichospermum (RAlfs ex Bornet et Flahault) comb. nova. Fottea 9: 59-64.

Zapomělová, E., Jezberová, J., Hrouzek, P., Hisem, D., Řeháková, K. \& Komárková, J. (2009). Polyphasic characterization of three strains of Anabaena reniformis and Aphanizomenon aphanizomenoides (Cyanobacteria) and their reclassification to Sphaerospermum gen. nov. (incl. Anabaena kisseleviana). - Journal of Phycology 45: 1363-1373.

Zapomělová, E., Jezberová, J., Hrouzek, P., Hisem, D., Řeháková, K. \& Komárková, J. (2010). Polyphasic characterization of three strains of Anabaena reniformis and Aphanizomenon aphanizomenoides (cyanobacteria) and their re-classification to Sphaerospermum gen. nov. (incl. Anabaena kisseleviana). Nomenclatural Note. - Journal of Phycology 46: 415.

(C) Czech Phycological Society

Received January 18, 2010

Accepted April 14, 2010 